\title{
The circular semiosis of Giorgio Prodi
}

\author{
Felice Cimatti \\ Dept. of Philosophy, University of Calabria, Rende (CS), 87030, Italy \\ e-mail: fcimatti@sophia.unical.it
}

\begin{abstract}
Prodi's semiotics theory comes into being to answer a radical question: if a sign is a cross-reference, what guarantees the relation between the sign and the object to which it is referring? Prodi rebukes all traditional solutions: a subject's voluntary intention, a convention, the iconic relation between sign and object. He refutes the first answer because the notion of intention, upon which it is based, is, indeed, a fully mysterious entity. The conventionalist answer is just as unsatisfactory for it does nothing but extends to a whole group that which cannot be explained for a single component; the iconic one, finally, is rejected too since in this case the notion of "likeliness", as the basis of the concept of "iconicity", is not explained. Prodi's answer is to locate the model of semiotic relations in the figure of the circle. The circle is life, which is nothing else but an infinite chain of translation and recognition relations amidst ever more complex systems. The circle has neither a beginning nor an end. It has no foundation, no established rule. It holds no cause that cannot become, in turn, effect. Semiosis, then, is based upon life for life, itself, is intrinsically semiotic. We can put the world in signs, that is we can come to know it, because we, ourselves, are a part of that very world that through us is made known. Finally, what this implies is that being inside the circle of semiosis-life, an issue arises what is beyond that circle: that is both an aesthetic and a religious problem.
\end{abstract}

\section{Introduction}

Giorgio Prodi (1928-1987) ${ }^{1}$ was, first of all, a scientist, an oncologist. It was as a scientist that he started questioning himself on the purpose

\footnotetext{
1 Biographical note. Giorgio Prodi was born in Scandiano (Reggio Emilia), in 1928 and died in 1987. In 1952 he graduated in Medicine, and later on in Chemistry as well, at the University of Bologna. From 1958 he taught in the same city general pathology
} 


\section{Felice Cimatti}

of his own activities. The things he would do when planning an experiment, how he went about doing those things, what his findings were - when the experiment was successful, that is to say, what was the nature of the object around which the experiment centered, and, mostly, on why knowledge was possible.

Traditionally, the issue of knowledge is presented, when reduced to its most elementary terms, as justifying the relationship between the one who knows - the subject - and what that knowledge is about, the object. How can the subject, which is free, meaning moved by reason, conscious, and active, know about the object, that, on the contrary, is moved by causes, thus falling under determinism, and is brute and passive matter? The problem of consciousness would be on how to reconciliate these two opposite poles, separated by a fundamental dualism. Posed in such terms there is no answer to this question, for however many attempts are being made, the object shall always be too far from the subject: if the subject is separated from the object, due to the fact it is made of matter different from the one of the object (as according to the current Cartesian vulgata, that would be the res cogitans in respect to the res extensa) or because it responds to different principles (the former acts when reasons move it, the latter follows causes), being it operates according to different modes than the ones on which the object functions (the former is active, the latter is passive), etc. Well, in all of these cases there is no sound justification to be had for the fact, as far-fetched as it may be, that knowledge is possible, and that the subject is seemingly able to interact efficiently with the world (McDowell 1994).

It is to this question, instead, that Prodi gave an apparently simple, and for this very reason, radical answer. His answer, instead of presuming dualism and discontinuity, rather takes into account the assumption of biological unity and continuity: "knowledge has 'stemmed' from things, and it can come to know about these as in so much as it is measured on them due to its own same origin" (Prodi 1974: 134). ${ }^{2}$

We are not the ones, as presumptuous subjects, to know the object, rather things alone let themselves be known by us. We are nothing but

and then experimental oncology. From 1973 he directed the Institute of Cancerology of his university. In addition to a vast experimental scientific bibliography (more than 300 publications), he has published novels and poetry works.

"La conoscenza è 'venuta fuori' dalle cose, e le può conoscere in quanto è dimensionata su di esse a causa della sua stessa origine". 
the ultimate transformation of other things, linked, in turn, to many others, and so on, all the way up to those very things we are presently knowing. The world does not account for an a priori distinction between subjects and objects which are separated and differ from each other, but only on more or less complex systems, all tied to an articulated web of relations that coincides with life (and semiosis and, hence, with knowledge, as we will see). If dualism is based upon a pattern entailing two separate poles that counter each other, Prodi's model is a biological one, concerning the evolution of living forms. In this model there are no halts but only ongoing transformations, living forms turning yet into other more or less complex forms of life. Subject and object cannot constitute the starting point of knowledge's developing process. Still they represent the final point, though never wholly attainable, for if such a full separation would ever occur, the biological continuity that links them, would break down. That would mean to say not the end of semiosis or knowledge, but of life itself. ${ }^{3}$

\section{The line and the circle}

To explain something means looking for a simpler fact or principle than the fact that one must explain, that is a fact or principle upon which the phenomenon which needs explaining must base itself. A thorough explanation should have an essential characteristic: if the phenomenon which needs explaining is found, say, at level $L$, its explanation $S$ must then be at least at level $L-1$. That is to say, the explanation will have to make a more proper use of terms than the ones it needs to explain. Nevertheless, when this kind of explanatory logic is applied to mental and, in particular, semiotic phenomena, it is spontaneous to come and believe that it does not function properly. An intentional explication seems to better respond to these types of phenomena, meaning that a fact can be explained by presuming it stems from an explicit intention for that very fact to take place. For instance, we may ask ourselves why a baby cries; according to the intentional explication the baby cries because in its mind lies the intention to attract the parents' attention. The mental phenomena, and among these particularly the semiotic ones, would be defined, and therefore ex-

\footnotetext{
In the text which follows I will go through some of the principal ideas of Prodi's vast work on semiosis. An ampler study of it can be found in Cimatti (2000b).
} 


\section{Felice Cimatti}

plained only through the intentions of those who partake in them (Buyssens 1943).

Such a conviction is strengthened by the idea that the use of signs rests upon an explicit convention (at least by and large), that is to say voluntarily. That the horse is named "horse", as this explication wants it, does not depend on how the horse is made but rather by the fact that is the way it has been decided, properly speaking due to a voluntary choice in this respect. Yet, then, all of the semiotic phenomena may be explained only through intentional notions, such as, for example, the voluntary one. An explanatory strategy of this type has a fundamental defect: it does not respect the rule illustrated here above, for it is more complex than what it would like to explain; if fact $F$ is found at level $L, S$ this time is placed at level $L+1$. Why? That is because we do not have access to what happens within people's mind, for we know nothing about intentions, we do not even know if intentions are real things as are bottle openers and philosophers. In this fashion the explication becomes more complex than what it would want to explain. Therefore, one cannot speak, in proper terms, of an explanation. More often than not, semiosis has tried to explain its facts through intentional explanations, that is by placing at the origin of semiosis a subject which voluntarily chooses to use a certain material object, the sign, in order to define something else, its meaning. As said before, this is no explanation in that it relies on a notion, as intention for instance, which cannot be summed up in something plainer. As Prodi himself observes (1982: 108): "The conscious is a fact to be explained through unconscious facts, even though usually there is a tendency to invert the points of the issue" ". One of the scopes of Giorgio Prodi's theoretical work, instead, is to try and explain semiosis by means of unintentional phenomena, thus truly respecting the norm that wants the explanation to be simpler than what it is explaining. While the intentional explanation can be illustrated by an arrow that descends from a higher to a lower level, with a criterion ranging from hard to easy, the unintentional one may be symbolized by an arrow heading the opposite way, as it goes from simple to complex levels.

\footnotetext{
4 "La coscienza è fatto da spiegare attraverso fatti non coscienti, anche se di solito si preferisce invertire i termini del problema".
} 


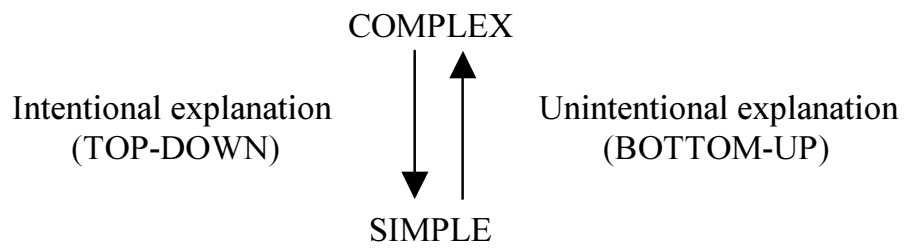

Figure 1. Non-biological explanation patterns. ${ }^{5}$

Still, if the strategy of the intentional explication seems hopeless, is its alternative, from lower to upper level, more efficient? Semiosis is a discipline that deals, primarily if not exclusively, with institutionalized current sign systems. Thus leaving the fundamental problem unsolved: if a sign is essentially a cross-reference, what guarantees the relationship between the sign and the object/thought to which it refers? Is it enough to appeal to social convention to establish such a relationship? Then, what does social convention, in turn, feed upon? Prodi's answer to this problem is to seek the origins of semiosis not in culture but, rather, in biology, or even better, in a biological method that closely considers culture in the relationships that are already established in different cellular entities.

Yet to consider biology altogether falling under the category of mediation, practically accounts for recognizing it as a single and infinitely complex web and interpretations of signs, likewise (Emmeche 1991). In this respect, however, one is quick to realize that Prodi's explanatory strategy is not even an unintentional reductionist one, that is to say one which attempts to undo, or properly reduce, complex phenomena in their simpler components. It is not so, according to Prodi, because the foundation of semiosis and language is, of course, in our world, but only given that the world is intrinsically already a language, meaning that it can be considered as an infinite chain of complex systems giving way to a continuous chain of other more complex combinations. Prodi's explanatory strategy then, cannot be represented by an arrow, regardless if it is directed from simple to complex or vice versa, but can be best illustrated with a circle (Lo Piparo 1992), that is a figure in which the end meets with the beginning. The subject is nothing but the last, and momentary, transformation of the object:

This diagram, as the following ones, is not Prodi's. 


\section{Felice Cimatti}

There must be a factual frame in which knowledge is a part of it, for without this frame knowledge itself could neither function, nor could it reproduce itself [...]. If we can know things (and in nature there may have been objects formed, able to know things) it is because a) there is an entire set of relations; b) this entity is "viable" with operations; c) it has produced systems that are, too, the "frame", that means they are included in the whole of the links, and employ actual present conditions, being that they are manifestations of it (Prodi 1982: 8) ${ }^{6}$.

The world is a "frame of facts", that is a whole of relations, not of separate and isolated things; this whole of relations, which is the world, defines the space of the "material logic found in the facts, in the relation of the elements on the horizon" (Prodi 1977: 43) ${ }^{7}$. This means, precisely, that the very world is intrinsically logical:

we are used to link logic uniquely with the functioning of the ability of thinking: yet if these are present in nature, their root is common to the one of material exchanges, in turn differentiated through more complex functions [...]. In this sense, logic, in its deeper step, is a material tautology. It is logic that which is (Ibid. $)^{8}$.

The world, furthermore, coincides with life, for the vital phenomena are the phenomena where relations and mediations prevail (CairnsSmith 1999: 72). In the world of life, in fact, every entity operates in accordance to a prime elementary form of "categorial logic" as Prodi calls it. A logic based upon selection, upon the discrimination of anything one may come in touch with and from which such a relation is not possible. A logic which produces the first implicit categories. Presently this "categorial logic [...] identifies itself with the general

\footnotetext{
6 "Deve esistere un telaio di fatti di cui la conoscenza fa parte, senza il quale né essa potrebbe operare, né potrebbe essersi prodotta [...]. Se noi possiamo conoscere le cose (e si possono essere formati in natura oggetti capaci di conoscere le cose) è perché a) esiste un insieme dato di rapporti; b) esso è "percorribile" con operazioni; c) ha prodotto sistemi che, essi pure, sono "telaio", cioè sono inclusi nell'insieme dei rapporti, e utilizzano condizioni di fatto presenti, essendone manifestazioni".

"Logica materiale [che] è nei fatti, nelle relazioni tra gli elementi dell'orizzonte".

"Noi siamo abituati a collegare la logica unicamente al funzionamento della capacità di pensiero: ma se queste sono presenti in natura, è perché si sono differenziate in natura, e dal momento che agiscono sulla natura, la loro radice è comune a quella degli scambi materiali che esse possono interpretare, essendo basate su una logica di scambi materiali, differenziati attraverso funzioni via via più complesse [...]. In questo senso la logica, nel suo gradino più profondo, è una tautologia materiale. È logico ciò che è".
} 
biological organization" (Prodi 1977: 83) ${ }^{9}$, that is, precisely, with life. At the same time, the world-life is also logic, a natural logic, a "web of facts, a material web" (Prodi 1982: 9) ${ }^{10}$, or, even more explicitly, "the initial operation is, then, a preliminary identification of logic with onto-logic" (Prodi 1982: 16) ${ }^{11}$. This web, this "network", is viable, it can be known because it is the very world-life model that produces "systems" that can get to know it. These systems are, in fact, nothing else but "manifestations" of that original network. The result is that having an outcome all but paradoxical for every model obtusely materialistic - the complex world-life-natural logic gets to know itself through its own sub-systems and manifestations: "from the very beginning, what is meant is the radical interpretation of how gnoseology functions internally to ontology" (Prodi 1982: 9) ${ }^{12}$. Knowledge becomes a function of being, a partial manifestation of being:

a frame of existing facts is the territory upon which one moves and in which, contemporarily, one searches for the explanation of moving. If there is an existing network of facts, and if we are part of it, our nature (structure, functions) stems from it, and as a specification of this, it can be neither contradictory nor external. We need not raise the issue of justifying the network, but rather being justified by it [...]. Such a network is then a continuity along our very selves: yet it is not to be estranged by us, as if we were globally external and opposed observers. We hold it within us, for our cognitive modes are simply one of its particular organizational methods. Through the network facts that are our make-up and the facts that connect us with the outer existence, we are submerged without any possible interruption in the most general web of facts (Prodi 1982: 15) ${ }^{13}$.

\footnotetext{
9 "Logica categoriale [che ...] si identifica con 1'organizzazione biologica in generale".

10 "Trama di fatti, una trama materiale".

11 "L'operazione iniziale è, dunque, una identificazione preliminare di logica con onto-logica".

12 "Fin da principio, s'intende quindi radicalmente interpretare la gnoseologia come funzione interna all'ontologia".

13 "Un telaio di fatti esistenti è il terreno su cui ci si muove e in cui, contemporaneamente, si cerca la spiegazione del muoversi. Se esiste un reticolo di fatti, e se noi ne siamo parte, la nostra natura (struttura, funzioni) deriva da esso, né è una sua specificazione, non può essere né contraddittoria né esterna. Non si pone per noi il problema di giustificare il reticolo, ma di esserne giustificati [...]. Tale reticolo è dunque in continuità con noi: ma non è qualcosa di estraneo, che possiamo vedere come osservatori globalmente esterni e contrapposti. Lo conteniamo all'interno, perché le nostre modalità conoscitive sono semplicemente un suo particolare modo organizzativo. Attraverso i fatti reticolari che ci compongono e i fatti che ci connettono a quanto è fuori, noi siamo immersi senza soluzione di continuità nella trama più generale dei fatti".
} 


\section{Felice Cimatti}

It is not, then, the hierarchical and foundation model (illustrated with the line and the arrow) to be the guiding image of Prodi's thought, rather it is the image of the circle; along a circle there is no single point that can be considered as the foundation of all others. The circle, on the contrary, represents the model of a world considered as an infinite series of complex entities' transformations yet into other, more complex ones, and so on. A transformation chain that never shrinks from the deep web that unites every living form to other forms of life. Let us go over this sequence of evolutive identities, in order to show the paradoxical outcome to which it leads: the first one is the webworld of relations that is equivalent to the material logic. The latter, in turn, can even be understood as life; but life, as it has already been pointed out, is coextensive with semiosis, and therefore with language:

it is clear that material logic and material semiosis coincide. If one material presence selectively interacts with another one [as it is specifically for categorial logic], becoming a reference-sign and startling it in an operational mode, such is a logical condition which is related with the impersonal assertion "each time that...", and it expresses the non-elasticity of the structure within which everything is imbibed, thus going beyond any reflection and incorporating any consideration (Prodi 1977: 44) ${ }^{14}$.

Therefore, life equals semiosis, that is, language: "biology is a natural kind of semiosis" (Prodi 1987b: 147) ${ }^{15}$. Still, for what concerns the transitivity of this identity chain, one reaches the identity resting between language and world (in so much as that the world is coextensive to life), from which one moves into tautology that is simultaneously beginning and end - in the circle figure every beginning is also an end, and vice versa - of the language corresponding to the same language. Tautology, in genetic terms, means that language is at the origin of language (Prodi 1987b: 93). In figure 2, we shall try and summarize this chain of identities (the targeted vectors represent the path of the process, to be considered as a contemporaneous evolutionary and foundational model) (Figure 2).

\footnotetext{
14 "È chiaro che logica materiale e semiotica materiale coincidono. Se una presenza materiale interagisce selettivamente con un'altra [questa è specificamente la logica categoriale], scoprendola come referente-segno e come innesco operativo, questa è una condizione logica, che è connessa con l'impersonale asserzione "tutte le volte che ...", ed esprime la non elasticità del tessuto in cui tutto è immerso, e che va al di là di ogni riflessione e che ingloba ogni riflessione".

15 "La biologia è una semiotica naturale".
} 


\section{Life $=$ categorial logic}

(every system selectively 'interprets' its own environment)

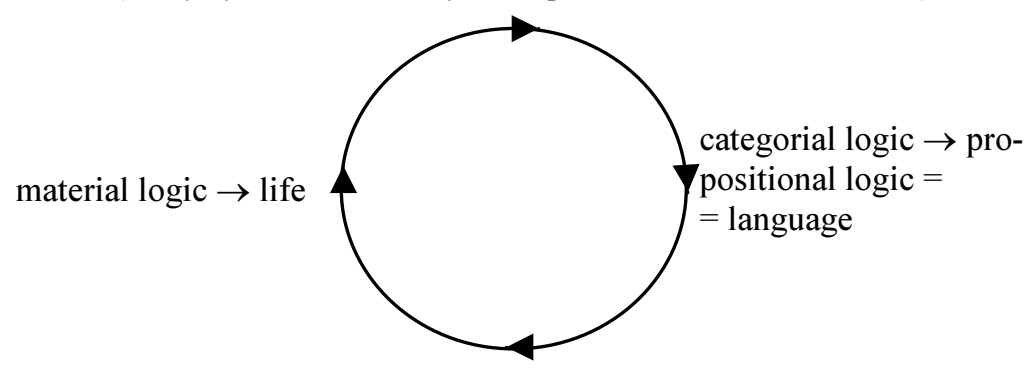

world $=$ material logic $($ frame of facts $)-$ world $=$ language

Figure 2. The circle as a founding pattern for semiosis.

The (apparent) final (world) language tautology = (human) language, in reality, is not properly so, for it gives an evolutive relation to time, from the world of language, as well as a foundational relation. Language is made possible, because it is nothing else but the last transformation of the very world, that in this respect can be described as its own product: "man - as Prodi affirms, and not by chance, with an Hegelian touch $-[\ldots]$ is a thought-up nature, [it is] inner nature" (Prodi 1987b: 93) ${ }^{16}$. Yet, already in this statement there is an implicit allusion to the dynamics internal to the circle, which, in reality, is not closed at all on itself (for if it really were it would render void language itself, to the extent there could not be any need whatsoever to express something already known), since the self-consciousness of nature is truly in continuous expansion. This means that the unknown regions, accessed through this former circular motion that developed into a spiral one, will be always more ample.

Language, according to Prodi, and semiosis generally, is not something of a distinctive nature from the world of life (Prodi 1988a). Language, and even its transformations, just as for society, culture, and history, do not counter nature, biology, and matter (Prodi 1988b). It is not, then, an attempt to simplify what is complex, as much as to show that what we believed being easy has, in reality, always been complex.

This also means, ultimately, getting rid of the distinction between simple and complex, as well as the disparity between arbitrary and

16 "L'uomo [...] è natura che si pensa, [è] l'interiorità della natura". 
iconic which represents its translation in the classical terminology of semiosis. For if language has always been a manifestation of the world of life, it also stands to say that it will never be able to pose itself the question of its major or minor "iconicity" in regards to that very world. Language is defined as a natural manifestation, and therefore it will never be separated from the world of life. Anyhow, the distinction between iconic and arbitrary supposes such a separation. In the end "iconicity" is a false consciousness of arbitrariness, that is the attempt to knit somehow together the relations between language and world after they have been severed through the notion of arbitrariness, whose function is to drastically separate language from the world. Yet, if this assumption is abandoned, the idea that language, as a full-way manifestation of culture, is different from the natural world, there no longer is any need to soften its excesses with iconic drugs. Once the dualistic model has been forsaken, why bother asking oneself if language is more or less closer and/or similar to the world? Furthermore, to sustain that (nature's) language creates (human) language, does not mean falling back into idealism, no more than affirming that nature gives way to culture means falling into materialism. The same is true of renouncing the notion of intention which is not the equivalent of reducing semiotic and mental phenomena to sheer causal concatenations. If life is semiosis this means that, ultimately, it makes no sense to ask oneself where to trace the boundary line between culture and nature, if ever one should try to understand how nature becomes culture:

Duality is not overcome by synthesis, rather by the ascertainment that at the very base of it all there is no duality. Thrusting forward the naturalbiological study of nature, on the one hand, we can see that in its most sophisticated and recent regions it becomes moral[...], on the other hand, returning to its origins, we can notice that every form of knowledge is innate in things. It is participation. It is likewise with man. The state of realities to be had is quite different from the one which we are accustomed to: things are speechless, yet they can answer when they are adequately questioned. By questioning them, one highlights one of their fundamental implications with the instruments that interrogate them, that is us. Our knowledge comes from far more ancient forms, all the way up to the roots of what is biological, that appears to be an "elementary knowledge" from the very initial steps of its organization (Prodi 1987b: 119) ${ }^{17}$.

17 "La dualità non è superata dalla sintesi, ma dal constatare che, alla radice, non esiste dualità alcuna. Spingendo a fondo lo studio naturale-biologico della natura, da una parte vediamo che nelle sue più sofisticate e recenti regioni essa diviene morale [...], dall'altra, risalendo indietro verso l'origine, vediamo che ogni forma di cono- 


\section{From biological complementarity to the semiotic triangle}

According to a classical diagram, the fundamental semiotic relation can be represented, approximately at first, with a triangle, in which a sign is related to a certain object, the sign referent, through the mediation of a meaning (Eco 1973: 25). This diagram, in the framework of Prodi's project for a biological foundation of semiosis, raises a radical issue: which principle guarantees the relationship between the sign and that which it is referring to? The most obvious solutions are those that seek the answer in the question itself or in the intentions of the subject, or in an agreement among subjects. An agreement which can be translated into a code, which should establish a list of correspondences between signs (meanings) and the corresponding objects, or in the fact that somehow the sign should be similar to the object (sign "iconicity"). We have begun to demonstrate tracing Prodi's steps, that the first idea is not an answer since it is based upon a principle, the intention or the consciousness of the subject, which is completely mysterious, whereas a good explanation should always rely upon facts simpler than those that need explaining. Even the code solution is truly unsatisfactory, for it does nothing but extending the first (pseudo) answer to the entire society that uses that given code: if there is no real justification for the fact that for the single subject the sign $\mathrm{S}$ is in relation with the object $\mathrm{O}$, why should we feel better if we take into account all of the subjects that use that same code? If the relation is unjustified for the one, it will be even more so by multiplying that one for all of those that make use of it. According to the iconic solution, finally, the sign would be in relation with what it is referring to because it would somehow look like it. Truthfully, not even this solution appears to be viable since the relation of likeliness does not seem to be a natural one, but rather, itself, be unconsciously based upon an estimated choice operation. For instance, whatever object $\mathrm{Q}$ is similar to whatever other thing Q1, not because it is naturally so, but because

scenza è connaturazione con le cose, è partecipazione. Così anche per l'uomo. Il quadro della realtà da conoscere è ben diverso da quello che ci si prospetta abitualmente: le cose sono mute, ma possono rispondere quando sono adeguatamente interrogate. Interrogandole, si evidenzia una loro fondamentale compromissione con gli strumenti che le interrogano, cioè con noi. La nostra conoscenza deriva da forme più antiche, via via fino alla radice di ciò che è biologico, che ci appare in sé come "conoscenza elementare", fin dai primi passi della sua organizzazione". 


\section{Felice Cimatti}

someone sees in Q1 a likeliness with Q. Therefore there is always someone finding a similarity, which is not something of a given in nature, but appears to be always in the eyes of the subject ${ }^{18}$. If this is so, "iconicity" rests upon a few instituted rules (and a rule said to be 'unaware' is by all means still a rule), hence it would be a somewhat arbitrary relation, and finally it could never constitute the undisputed foundation of the relation between the sign and what it refers to. If "iconicity" is understood as something that has to do with resemblance it cannot represent the solution for the problem of the foundation of semiotic relation. In the semiotic model, that we can define as Cartesian, the sign is inscribed to hold, as in the case of the subject in regard to the semiotic instrument it uses, no link with what it is indicating. Such an original separation makes it difficult for any attempt to bring back together these two wholes, the subject and the object.

To answer the question we asked ourselves earlier, that is what does the semiotic relation rely upon - it is necessary to take into consideration not the semiotic triangle under way, but rather ask oneself how are the first proto-semiotic interactions in nature, and thus within the phenomena of life, born. Prodi's starting point is the concept of natural significance:

the most general condition for a language situation (that is retrieval and transmission of sense) is significance, the condition for which a natural presence is correlated to another natural presence through a relation of selectivity. This condition is at the origin not only of language as it is normally intended, but of the entire biological organization: which is, according to this point of view, intrinsically linguistic (Prodi 1983b: 186) ${ }^{19}$.

Let us take into consideration an absolutely elementary situation, illustrated in figure 3: an organism $A$ that explores its environment. Inside this environment, to make it easier, there are only four objects $B, C, D$, and $E$. A has a certain make-up, for instance, if $A$ is a protein, the atoms that form it will give it a particular spatial configuration, that is a

18 We are before the classical critique of Eco (1975) on the notion of "iconicity". Yet, while for Eco this critique had the function to defend a completely arbitrary position, in our case it helps to make way for a biological model of semiosis, which is neither arbitrary nor iconic.

19 "La condizione più generale per una situazione di linguaggio (che è reperimento e trasmissione di senso) è il significato, cioè la condizione per cui una presenza naturale è correlata ad un'altra presenza naturale attraverso una relazione di selettività. Questa condizione è alla base non solo del linguaggio come normalmente inteso, ma di tutta l'organizzazione biologica: la quale è, sotto tale punto di vista, intrinsecamente linguistica". 
particular ability to come in touch with certain object forms excluding all other forms. In the $A$ environment the only other object it is possible to come in relation with is $B$, meaning that $A$ and $B$ have a specific complementarity. Using a metaphor that Prodi often employs, between $A$ and $B$ there is an analogous relation to the one that a door lock and the only (at least in theory) key to open it share. $B$, in respect to $A$, represents the only meaningful portion of its environment (or, to use another terminology "pertinent"): "significance is a categorization: a sign, that is interactive selection" (Prodi 1982: 169) ${ }^{20} . B$, for $A$, is a sign that 'means' the relation it can, in fact, have with $A$. However, at this all but primitive semiotic level, $B$ is a sign that is identical to its referent, that is, $B$ does not refer to else but itself: in $B$ the sign and the referent coincide. Properly said, the semiotic triangle is in turn a point to reach, for the "boundaries of the semiologic relationship are initially only two [...] mediation (the autonomy of the sign) is subsequent" (Prodi 1977: 158) ${ }^{21} . B$ for $A$ 'means' an object with which it is possible to come in touch, and with which it can form a more complex system, an agglomerate $[a b]$ :

A

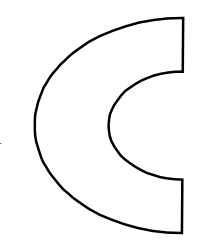

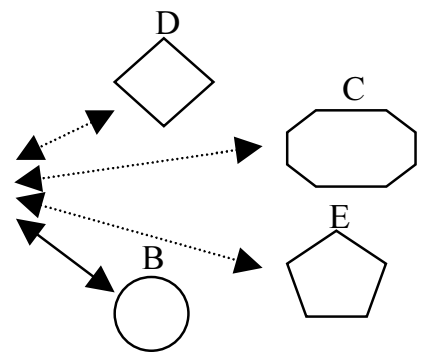

$\mathrm{AB}$

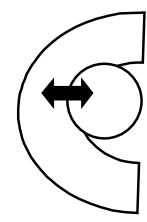

Figure 3. The origins of semiosis as a natural significance.

At the beginning neither is $A$ a subject nor is $B$ an object, since the subject is such only in respect to something which counters it (an object), just as an object needs, from a biological point of view, in so much as that all of Prodi's model is not but a reconstruction of semiosis in biological terms, a subject in order to define itself as such. At the same time $B$, as previously noted, is a sign for $A$, in the sense that

\footnotetext{
20 "Il significato nasce come categorizzazione: è segno, cioè interazione selettiva".

${ }^{21}$ "I termini del rapporto semiologico sono inizialmente due [...] la mediazione (l'autonomia del segno) è posteriore".
} 


\section{Felice Cimatti}

it is intrinsically endowed, in $A$ 's respect, with a certain significance for it is important coming from its point of view. $B$ is not only an object. It is an object that means something for yet another object (that special object which Prodi refers to as a "reader"): "the sign is not the thing, but the thing in relation to a reader: the sign is the existence of a deciphering, or relationship, or reaction specificity process" (Prodi 1982: 169) ${ }^{22}$. In this respect the foundation problem on how to justify the union of a sign with what it indicates is overcome since $B$ is, at the same time, sign and referent. The sign, in biological terms, comes into being as a union, as a continuity:

our problem is: how is this significance situation, for which a thing is a sign for an interpreter possessing its code, born in nature [...]. In this case, the sign does not have two sides, there is no semainon nor semainomenon. The sign is a thing. A thing becomes a sign when a reader that can interpret it appears and "picks it up" selectively. The selection, that is the specific relation conducted by a sign interpreter: such is the origin of semiotics (Prodi 1987b: 146) ${ }^{23}$.

The basic situation represented in figure 3 can now be sketched in figure 4 . The classical semiotic triangle flattens in the complementary bijective relation between the reader $A$ and the object $B$ (the sign/referent), a relation from which stems the formation of the complex object $[A B]$ :

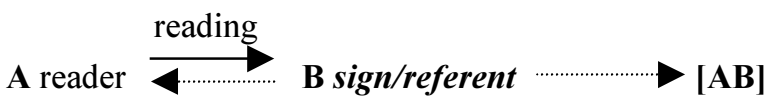

Figure 4. Non-triangular pattern of the sign.

Extended chains of natural significance form on the basis of protosemiotic complexes (as in the case of $[A B]$ in figure 4 ), that is, living organisms which are "complex federations of significance interpretation, coherent and capable of expressing their own sought-out reading

\footnotetext{
22 "Il segno non è la cosa, ma la cosa in rapporto a un lettore: il segno è esistenza di un processo di decifrazione, o rapporto, o reazione di specificità".

${ }_{23}$ "Il nostro problema è: come nasce in natura questa situazione di significato, per cui una cosa è segno per un interprete che possegga il codice [...]. In questo caso il segno non ha due facce, non c'è semainon e semainomenon. Il segno è una cosa. Una cosa diventa segno nel momento in cui compare un lettore che la può leggere, che la "prende su" selettivamente. La selezione, cioè la relazione specifica condotta da un interprete del segno: questo è l'inizio della semiotica".
} 
advantage on the surroundings. In this respect one can speak of the intrinsically "linguistic" character of biological objects" (Prodi 1983b: $189)^{24}$. From such an indication one may also infer an idea about how, according to Prodi, the mind my function: "a network (united in its decentered entirety) more than [...] a hierarchical type of unit, that can be represented as a system of vertically-placed filters" (Prodi 1983b: $176)^{25}$. The hierarchical system is completely compatible with the classical Cartesian model, the one that sees consciousness at the zenith as an uncaused cause in that it is formed by a substance which is altogether different from the one found in the rest of the brain (Eccles 1996). A concept of this kind is incompatible with Prodi's naturalistic model, for it places at the top of the whole system a mysterious res cogitans, by definition irreducible to a simpler form: "we do not have the pretence of explaining the language with an extra-natural intervention of an "intentional" kind" (Prodi 1983b: 314$)^{26}$. The mind, instead, according to Prodi, is, in fact, a network, a complex federation of significance interpretation chains, a material network, notwithstanding how astronomically complex, of situations like the one represented in figure 4 (Cimatti 2000a).

In Prodi's model, then, the separation between sign and referent as seen in the classical semiotic triangle will never occur. It can be observed only to the extent that we have lost all recollection of their original spatial contiguity when the translating chains that link the first to the second are extremely prolonged. Thus, their separation is, as said before, only apparent: the sign is always contiguous to its object, what varies, instead, is the extension of the translating chains. Though if continuity is the major characteristic of semiosis, once again returning to the model of the circle, there will never be a radical separation between sign and referent. That leads, in turn, to flattening the semiotic triangle in a continuous transformation line of entities in other more complex ones:

the two faces of the sign occur from the moment when there appears a sufficiently complex code in nature; yet, if we were able to undo a sign in its various steps, we would discover [...] that every step is formed by a

\footnotetext{
24 "Federazioni complesse di letture del significato, coerenti e capaci di esprimere sull'intorno il proprio raggiunto vantaggio di lettura. In ciò risiede il carattere intrinsecamente "linguistico" degli oggetti biologici".

25 "Più un reticolo (unitario nella sua globalità decentrata) che [...] una unità di tipo gerarchico, rappresentabile come un sistema di filtri disposti verticalmente".

26 "Noi non pensiamo di spiegare il linguaggio umano con un intervento extranaturale di tipo "intenzionale"“.
} 
reader-thing that interprets another thing which, in turn, is seen as a sign, that is, subsequently read by yet another thing. All the molecular processes that we are beginning to be aware of rather well, in the present-day, (from the proteinic synthesis to the employment of energy, from the duplication of the DNA to the transmission of nervous drives) belong to this typology. Man's cerebral functioning is surely terribly complicated [...] but it is hard to believe that it may operate differently from a continuous molecular recognition of significance (Prodi 1987b: 147) ${ }^{27}$.

\section{On the borders of the circle: the aesthetic experience and the religious problem}

Prodi affirms that our knowledge of the world cannot avoid passing through the filter of a theory, that is a network of hypotheses. In this respect, the knowledge of the world is nothing but another manifestation of language. In this very categorization it is clear that there will always be something that will pass through the nets of such a framework given that 1) a network is made in a way to relinquish something from its meshes; a network is made-up of knots and each knot is tied to another, and no matter how closely-knit this web can be there will always be empty spaces between knots. A network is selective, that is, every network will let something go by, hence any hope of having absolute knowledge of reality is nothing but an illusion. An illusion because it is logically impossible (and therefore, according to Prodi, ontologically and semiotically, too) to strive for an ultimate understanding of the world; 2) every network, no matter how extended, is nevertheless limited. A bigger network would be useless as it could hardly function. Yet, if every network must be (more or less) small it means that the attempt to use it in exploring the total surface of the sea is by definition unattainable. Knowledge might even single out very large portions in that infinite sea of the knowable yet they remain limited. Once again, it is the figure of circle that explains this situation.

\footnotetext{
27 "La doppia faccia del segno si ha dal momento in cui si pone in natura un codice sufficientemente complesso; ma se riuscissimo a smontare un segno nelle sue varie tappe, scopriremmo [...] che ogni tappa è formata da un lettore-cosa che legge un'altra cosa che diventa segno per lui, e questo a sua volta è letto da un'altra cosa. Tutti i processi molecolari che oggi cominciamo a conoscere abbastanza bene (dalla sintesi proteica all'utilizzazione dell'energia, dalla duplicazione del DNA alla trasmissione degli impulsi nervosi) sono di questo tipo. La funzione cerebrale dell'uomo è certo di una complicazione terribile [...] ma è difficile pensare che essa funzioni in modo diverso da un continuo riconoscimento molecolare di significatività".
} 
The logic of language as a generative whole defines a space indefinitely extended, for there is no superior limit, at least in principle, in regard to the admissible sentence combinations in our language. Anyway, such a whole, regardless of its great size, will be a mere fraction of the entire infinite within which the rules of our language are (still) not valid. The inherent logic of language defines two complementary spaces: the one in which its rules are valid, and that coincides with the world, our world (for we hold no other access to the world than the one mediated by knowledge = language), and the other one, containing the former and being infinitely more extended than that one, in which such rules are not valid, as we will attempt to show in figure 5:

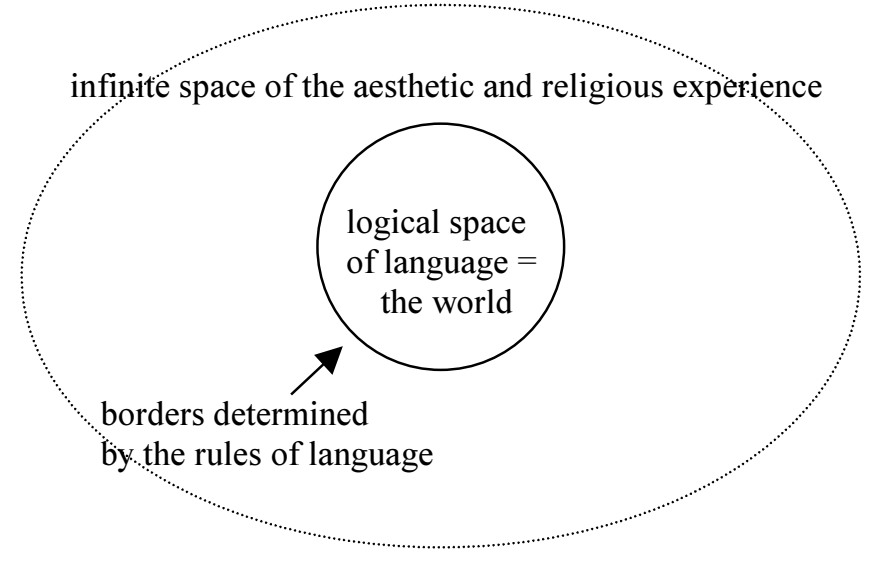

Figure 5. The biological origin of the aesthetic-religious issue.

Thus, we have reached the problem of borders, that is the aesthetical question together with the theological one. For Prodi, they are both determined by logic even prior to the feeling of beauty or fear of the unknown: "sacredness is, then, from such perspective, a precise drive that embodies logic" (Prodi 1987b: 119) ${ }^{28}$. Language, understood as a circle, defines two concentric spaces: we are inside the space of language, and by definition we cannot go beyond the limits imposed by its inherent logic, for we cannot think outside the language. Every single conceivable access to the world must pass through language. Every thought is determined by language, and therefore that which is

28 "Il sacro è dunque, da tale prospettiva, una pulsione precisa che fa corpo con la logica". 
not governed by the rules of our language is unthinkable. Since our language determines a space, and we are within that given area, it brings about the logical need, that however cannot be further defined, of all that which is external to our very language field. Logically we can recognize that there is no space outside the logic, that is, our logic, yet this space, just as logically, is unattainable, unknowable, unthinkable. Here, then, there is more space for the possibility, that is historical and evolutive logic, of those experiences that are found at the very borders of language, both aesthetic and religious:

[human reality] is not only composed of objects $A, B, C$, and so on, including those hidden objects that are highlighted and seized by language, but also (and ever more) by those objects that are not there. Knowledge is, in fact, from its very start, firmly tied to the unknown. If an animal reacts towards his significative terms, they alone exist. The animal does not pose itself the question of whether things exist or do not exist at the borders of its own categories. When knowledge becomes propositional and reflexive, there is a contextual incertitude that arises in so much as it is not characterized by the speech thus settles in the problem of the borders beyond which there is a reality which cannot be attained (Prodi 1987b: 118) ${ }^{29}$.

The undeterminable space that extends beyond the limits of the language-world, now becomes the only scope of experience which we can aspire to. For everything that precedes it, which we can learn through language, we shall know sooner or later (such is the scope of science) as it has always been determined this way, just as for Prodi it is because semiotics and ontology coincide.

Within the circle, instead, we are attracted by what is outside it. That is, what is defined as that which we cannot know, because the logic of our life and of our language prevents it: "hence, the fundamental issue is borders: what we are unable to understand, what lies beyond the boundaries, and for which we have no categories" (Prodi 1987b: 212$)^{30}$. This indefinite and extra-logical space, in particular,

\footnotetext{
29 "[La realtà umana] non è solo composta dagli oggetti A B C e via via dagli oggetti nascosti che vengono evidenziati e catturati dal linguaggio, ma anche (e sempre più) dagli oggetti che non ci sono. La conoscenza è infatti, fin da principio, solidalmente legata alla non-conoscenza. Se un animale reagisce verso i suoi termini significativi, solo essi esistono, non si pone per lui il problema di ciò che forse c'è e forse non c'è al di là dei limiti delle sue categorie. Nel momento in cui la conoscenza diventa riflessa e proposizionale, si pone contestualmente l'incertezza per quanto non è caratterizzato dal discorso: sorge il problema dei confini oltre i quali c'è una realtà impredicabile".

${ }_{30}$ "Dunque, il problema fondamentale è quello dei bordi: ciò che non riusciamo a capire, ciò che sta oltre i confini, per cui non abbiamo categorie".
} 
can be known only from within: "no reader can exit reality and contemplate it from outside. One may read only from 'within', that is inside a complex of interactions" (Prodi 1983a: 17) ${ }^{31}$. This area beyond language may be reached through two distinct yet linked ways. Firstly, through a hypothetical process of the extension of language itself, in a way making an attempt to redirect the unknown to the known. Secondly, entirely admitting the logically inescapable fact of the limit of the space determined by the language-world circle. The first possibility is aesthetical, and in particular poetic, while the second one is religious.

Let us return to the language-world circle of figure 5 . The human animal coincides, for what it holds of specifically human, with its language. Language defines the borders of the human world due to its biological complementarity between the reader and the organism read (v. supra, figure 2): "an organism knows-interprets (has a specific relation with) the reality on which it has formed itself. It interprets the world together with its categories, even though it is such a world that has built those very categories" (Prodi 1987b: 143-144) ${ }^{32}$. Given that the whole of what is known is coextensive with the whole of the language, the boundaries of the world coincide with the borders of what the (innate) rules of language allow us to think-say. The point is that, as previously said, our human experience is completely within that circle, yet this does not prevent us from understanding that beyond it, where our categories are useless, there is an outside that although unknown, nonetheless attracts us, and regardless of the fear we feel we have an urge to explore and get to know it. This feeling occurs, once again, inside the circle. We are aware of the fact that our knowledge, that is the whole of operations with which we recognize as significative certain portions of reality (as this is the true point, only some portions, not the entire reality, by definition unreachable by beings endowed with only a particular point of view), is meaningful only in relation to an infinitely more vast region of the unknown, "[which] is [...] a fundamental constituent of the speech, and brings into speech the burden of all the existing things of which, though, we have no documentation. Therefore, the word implies a non-word, not through

\footnotetext{
31 "Nessun lettore può uscire dalla realtà e contemplarla da fuori. Si può leggere solo "dentro", cioè dall'interno di un complesso di interazioni".

32 "Un organismo conosce-interpreta (ha relazione specifica con) la realtà su cui si è costruito. Interpreta il mondo con le sue categorie, ma queste categorie quel mondo stesso le ha costruite".
} 
games of dialectics but rather thanks to the mechanics of speech genesis" (Prodi 1983a: 40) ${ }^{33}$. Knowledge, as we said, is the natural operation through which one asserts that something, in respect to a myriad of other possible and alternative 'somethings', is significative. What is not significative, on the contrary, remains in the background, just as any word that defines itself in relation to an ampler space of speechlessness, and is thus destined to remain unknown as well as unthought of. Yet, this implies that the unknown (the region without boundaries that extends to the exterior of the area of the circle in figure 5) is always present, in the form of background or as an indefinite horizon of (possible) knowledge. "If what is called "rationality" is the whole of modes in which man has learnt to humanly manage a certain area of reality (that has become a little more its own), the rational is, then, a small space cut out in the irrational, always placed within it. The rational is a tiny "organized irrational"" (Prodi 1983a: 41) $)^{34}$.

The aesthetic experience, that for Prodi is all but restricted to that of beauty or art, is the one felt in the proximity of that boundary. The aesthetic experience is akin to the cognitive one. It represents the initial, hypothetical, explorative moment because a strong "cognitive drive" is at the base of it. Aesthetics is present wherever, coming from the experience of a precise cognitive placement, within the languageknowledge circle, one attempts to thrust himself beyond it, towards the exterior. As Prodi himself says, the unknown, or towards the "dark" (being, as we shall see further on, another way to characterize that which for the religious experience is god, unknowable and always exceeding our limited tools to circumscribe it):

The main nucleus of aesthetic quality deals with our own undecided placement, meaning our own being, entirely, the very object of that wavering that characterizes the borders (and further): our own selves being most likely beyond those borders, unknown to us in a radical fashion, unable to act with decisive introspection, with direct shortcuts, even when

\footnotetext{
33 "[Il quale] è [...] un costituente fondamentale del discorso, e porta nel discorso tutto il peso delle cose che esistono, ma di cui non abbiamo documenti. Quindi la parola implica la non-parola, non attraverso giochi dialettici ma attraverso la meccanica della genesi del discorso".

34 "Se chiamiamo "razionalità" l'insieme dei modi in cui l'uomo ha imparato a maneggiare umanamente una certa area di realtà (che è diventata un po' più sua), il razionale è allora un piccolo spazio ritagliato nell'irrazionale, sempre depositato nel suo interno. Il razionale è un minuscolo "irrazionale organizzato"”.
} 
really close to ourselves, almost as if coinciding with our own center, if ever there is one (Prodi 1987b: 216)

Having linked anxiety with the experience of the limit, the human animal has its own way to respond to uncertainty. It does so with an hypothesis, with an attempt to extend to the unknown and to the future what is worthwhile for the known and the present-day (and thus the past):

hypothesis and doubt are two aspects of the same mechanism [...]. It is hypothesis [...] that transforms the knowable world. Doubt itself refers to areas of reality which are larger than those that we have experienced: it is relative to the area of "non-significative" things which can become significative; it is the possible area. It is not a sheer psychological state. It is res extensa adequate enough to be considered linguistic organization" (Prodi 1983a: 38) ${ }^{36}$.

The hypothesis is not (yet, and might never be) justified, in so much as it is a hypothesis, that is, an attempt at extending the boundaries of the known at the expense of the unknown. The hypothesis is actually such for it is not justified, because if it had been justified, it would have ceased to be, appropriately, a hypothesis, and thus the clause would return amidst proven facts, scientifically described, that is, facts internal to the language-world circle.

The role of language is central in the construction of hypothesis: that we may bring forward having the avail of language's combinatorial resources, which allow us to internally generate those clauses (still) unrestricted by the exterior world's characteristics. In fact, hypothesis is (relatively) free given that language as a combinatorial machine allows to produce an indefinite number of terms, each of which may represent a possible explorative path. A way to grasp, in the space external to the language-world, contents that were just waiting

\footnotetext{
35 "Il nucleo duro dell'esteticità è una certa nostra collocazione indecidibile, cioè l'essere noi, integralmente, proprio l'oggetto di quella indecidibilità che caratterizza i bordi (e oltre): l'essere noi presumibilmente già oltre i bordi, cioè oscuri a noi stessi in modo radicale, impossibilitati ad una introspezione decisiva, a scorciatoie dirette, ancorché vicinissimi a noi stessi, quasi coincidenti col nostro centro, ammesso che ci sia".

36 "Ipotesi e dubbio sono due aspetti dello stesso meccanismo [...]. È l'ipotesi [...] che trasforma il mondo conoscibile. Il dubbio si riferisce a zone del reale più larghe di quelle di cui abbiamo esperienza: è relativo alla zona di cose "non significative" che possono diventare significative; è l'area possibile. Non è un semplice stato psicologico. È res extensa passibile di organizzazione linguistica".
} 
to become, using Prodi's terminology, significative, to select a reading machine that may interpret them:

[the hypothesis is] a fantastically processed original nucleus [...]. Hypothesis is a fantasy situation, meaning a cerebral de-facto state characterized by the subject's ability to autonomously have its own linguistic materials, without any environmental-external dependence on selections or restrictions or censorship, from feedback unto reality. It is considered a structure's material state. The inner space extends to the outer space, that is the pole of knowledge: though it is temporarily isolated from it during the operativeness of the hypothesis (Prodi 1983a: 209) ${ }^{37}$.

The hypothesis is intrinsically cognitive, but even inherently aesthetic, that is to say poetic, for it rightly is an internal experimentation. A word game that seems to act according to a purely combinatorial logic, though, also in this case, it produces what we may refer to as "cognitive tentacles" with which to tear shreds of "darkness" from the unknown in order to make them knowable and expressible. Through the auxiliary of hypothesis a kind of surrealist bridge, resting on a single bank that is internal to the language-world, is built, while on the other bank, initially, it is suspended. It rests supported only by its own weight, and however paradoxical it might sound, it is not considered so, which, in turn, is the true paradox inherent in the hypothesis. Such a paradoxical condition comes from the logical impossibility of speaking about what is beyond the borders of the language-world. By definition, for anything which is found beyond the borders of the expressible-knowable nothing can be said that would make any sense. That is because none of our clauses can be accepted or denied in regard to the pro or con proofs relative to it.

Let us return, once more, to figure 5 . The aesthetic dimension of language, places us, as it has been said earlier, on the outskirts of the world. On the outskirts, or right over the boundary line where, logically, we could not stand even though we try and stay there, anyway, by using the instruments of analogy, that is a particular linguistic procedure in which the old projects himself into the unknown in order to

\footnotetext{
37 "[L'ipotesi è] un nucleo originale di elaborazione fantastica [...]. L'ipotesi è una situazione di fantasia, intendendo con ciò uno stato di fatto cerebrale caratterizzato dalla capacità del soggetto di disporre autonomamente i propri materiali linguistici, senza alcuna dipendenza da selezioni o restrizioni o censure esterne-ambientali, da feed-back sul reale. Essa è uno stato materiale della struttura. Lo spazio interno si continua con lo spazio esterno, che è il polo della conoscenza: ma ne è isolato temporaneamente durante la operatività dell'ipotesi".
} 
see if it works there too. Even that portion of "darkness" covered by our hypothesis is governed by the same laws of the known, the already known. The hypothesis, then, is based on the analogy:

the analogy functions aesthetically in the direction of darkness, as an attempt to translate/enlarge our area towards it, in terms of verbal meanings. They are unverifiable. They do not make any sense in their providing with objective references. At the base of this is a radical analogous mechanism [...]: to yield our point of view in the dark, to be watched by eyes that we cannot see. To be watched by things rather than looking at them: even from their hidden sides (Prodi 1983a: 207-208) ${ }^{38}$.

This means that, thanks to the aesthetic use of language, the boundaries of the language-world extend. At first, they extend only hypothetically, but then, if the analogy holds firm, even cognitively, as we try to point out in the diagram below, where the hypothesis-analogies stretch out those "tentacles", which we talked about earlier, in the unknown, in the "darkness":

analogic-aesthetic extension of language's boundaries

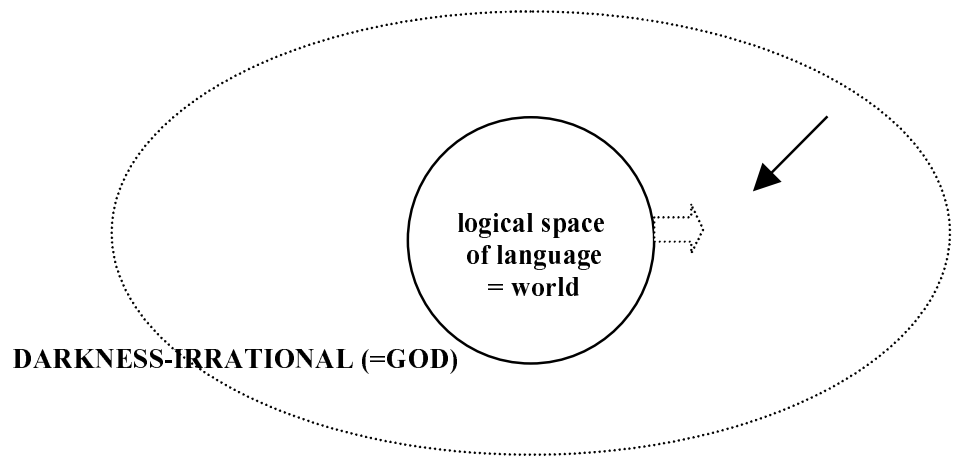

Figure 6. The hypothesis of poetry that extends knowledge into the "darkness".

\footnotetext{
38 "L'analogia funziona esteticamente nella direzione del buio, come tentativo di traduzione-allargamento dell'area nostra verso di lui, in termini di costrutti verbali. Essi sono inverificabili, non hanno senso nella loro referenzialità oggettiva. Alla loro base vi è un meccanismo analogico radicale [...]: cedere il nostro punto di vista al buio, essere guardati da occhi che non vediamo. Essere guardati dalle cose, anziché guardarle: anche dal loro lato nascosto".
} 


\section{Felice Cimatti}

If the aesthetic is akin to science, all along, given that in both cases it has "to digest the unknown with the digesting system of a language that works" (Prodi 1983a: 208-209) ${ }^{39}$, nevertheless, it still accounts for the logical, yet entirely insurmountable fact that neither of the two experiences can help us relax our minds before the undetermined fall of darkness. In addition, knowledge, regardless if scientific or aesthetic, stems from the attempt to practically overcome that anxiety, yet at the same time, due to its partial and almost compensating nature by definition, does nothing but reassert our unsatisfaction, our feeling of narrowness and finitude. Before our logical eyesight there always lies the boundless vastness of the unknown, "of that full length [...] prevailing outside us [...] the region of what is inexpressible" (Prodi 1983a: 195$)^{40}$, that is referred to by many, in ordinary vocabulary filled with an anthropomorphism which is unfamiliar to Prodi, as God. Herein, seen neither as someone nor as something, but if anything, as the matrix of every determined something, and in particular this region represents the speechless and dark horizon of our unsatisfaction as linguistic animals, that can produce hypothesis because, through language, we reach the awareness of living in a closed world, even though deep inside it is indefinitely extended.

The religious problem stems from what we may call a logical sensation that cannot be done away with, if we may use an oxymoron, being that we are within the language-world circle, and it is not possible to observe the circle from the exterior, it would mean relinquishing our logic and our language in order to adopt yet another one. Though this is naturally (logically) impossible. We are children of that language and cannot renounce it at our liking. This is to say that we are finite, logically finite, and we are such in respect to an infinite that exceeds, towers, and oppresses us. Thus, the religious problem is more similar to logic than to feelings, for it is through logic that we become practically and essentially aware of our limits: "sacredness then, in such a perspective, is a precise drive that embodies logic" (Prodi 1987a: 119) ${ }^{41}$. In this sense the religious problem, and so much for all the materialistic utopias of a world without God, is inscribed in our own being.

\footnotetext{
39 "Digerire il non conosciuto col sistema digerente di un linguaggio che funziona".

40 [Quel']"esteso e [...] prevalente fuori di noi, [...] la regione dell'indicibile".

41 "Il sacro è dunque, in tale prospettiva, una pulsione precisa che fa corpo con la logica".
} 
The materialistic and functionalistic explanations of religion try to explain its origin by linking it to the feeling of panic, fear of the unknown, thus connecting it to the most obscure and blindfolded drives of our mind. By so doing they create a sentiment that, at least in theory, might be overcome one day thanks to an adequate education, sufficiently developed scientific knowledge. In Prodi's approach, on the contrary, the religious problem is intrinsically inscribed in our minds. This does not mean to say, according to the trivial belief that the idea of God is innate (although this does seem as a captious and circular justification of religion), as much as it signifies that our deeprooted linguistic make-up naturally brings us, through the aesthetic experience of hypothesis, to question ourselves on the limit, and to wonder, what could or could not be beyond that point. In this sense the religious experience is akin to an instinct, a very particular logical instinct, yet another oxymoron, that is totally a whole with our being intrinsically and radically linguistic animals:

In the complex, the hypothesis suggested is opposed to the anthropological and ethnographical theories based on the absolute irrational originality and primitivity of sacredness, pertaining to a rudimental phase of civilization. They invariably take into consideration an already genetically constituted man. Whereas what is being affirmed, instead, is the that the origin of sacredness must be anticipated to the phase of man's rational formation, otherwise said of its specific differentiated traits. For it is contextual to logic and morality. Sacredness characterizes the passage from non-man to man, and collaborates to building its specificity (Prodi 1987a: 118$)^{42}$.

\section{Conclusions}

The circle is a figure without a beginning or an end, it does not have an absolute before and an absolute after, and it lacks a foundation and an established rule. The circle, as we have tried to explain, constitutes Prodi's model of semiotics. Semiotics that, in reality, aspires at doing

\footnotetext{
42 "Nel complesso, l'ipotesi che si propone è in contrasto con le teorie antropologiche ed etnografiche basate sulla assoluta originalità e primitività irrazionale del sacro, proprie di una fase rudimentale della civiltà. Esse prendono invariabilmente in considerazione un uomo già geneticamente istituito. Qui si vuole affermare invece che l'origine del sacro va anticipata alla fase della formazione razionale dell'uomo, cioè propriamente dei suoi caratteri differenziali specifici. Esso è contestuale alla logica e alla morale. Il sacro caratterizza il passaggio dal non-uomo all'uomo, e collabora a costruirne la specificità".
} 


\section{Felice Cimatti}

much more than just defining and determining the field of intentional and conscious signs use of, let alone human signs. Prodi uses the circle to show how, at the moment, human semiotics is the last phase of an evolution that with a total continuity, which however does not eliminate altogether the possibility of radical new experiences, refers back to natural semiotics, to those natural exchanges, that is material logic, which entail, and whose full meaning is, life. Life, in this respect, is intrinsically semiosis. Thus life, semiosis and material logic are biologically coextensive terms. Still, since human language, through the mediation of categorial logic, is the direct prosecution of worldly life, of natural semiosis, the very language is, through an evolutive identity, life. Hence, the circle comes a full way round and starts closing in for the possibility of language, which Prodi tell us is also knowledge, to say that the world derives from the fact that, in the end, language and the world share the same make-up. They are the same thing under different combinations ${ }^{43}$.

The circle, however, becomes a spiral. An open spiral for if language is knowledge it is even capable, thanks to its aesthetic customs and therefore through hypothesis, to extend the world's boundaries since, as in so much as initial identity, language and world are coextensive. The evolution of the human world is, then, indefinitely open. As we have seen, this opening, this inherent possibility of extending the world's boundaries implies, straight away, and implies logically at that, the existence of an infinite spatial region beyond those borders, which Prodi calls "darkness". That is the unknown and unknowable region within which our language is not valid. A region, nonetheless, of which our world is not but a restricted portion that rests upon and originates from this very region. This region is what we could call God, even though it would refer to a strange type of God since it would be no person, it would concern neither an order nor a presence but if anything at all, instead, a kind of absence. It would be more of an emptiness that attracts us and makes us worry, while thrusting us to explore it and inquire about it. A God, granting that Prodi would have allowed such an improper use of this term in his semiotic reconstruction, in this respect, that would have given (paradoxically speaking, for we have excluded that it may be someone or something) us an assignment. A paradoxical assignment, actually, because it would deal with a duty that no one explicitly assigned. A task, indeed, that would

43 As Lo Piparo (1999: 200) states "a theory on the world is a part of the world that observes the world". 
grow spontaneously within the human animal and not from some external authority. Still a duty that arises from the evolutive depths of man, for his linguistic ability, as it has been already pointed out, is nothing but complicated and innovative development yet free of any elementary stalemates of semiosis and, hence, of life, itself, which, for Prodi, is essentially semiosis.

The task of knowing and thus naming things, then, would be an assignment that comes, precisely, not from the outside, that is, a world superior to our own. On the contrary, it is an issue that stems from us as in so much as we are animals, because we are radically linguistic animals. We are at the heart of the circle, and this is another paradox. Around the perimeter of the circle there is no center, no heart to be had: the duty that makes things want to know about other things, and therefore know themselves, is given to us by our very nature, and thus, by our own selves. Still, it seems as if the order came from somewhere else from here, that is elsewhere but at the same time coinciding with us. In the circle, tautologies seem to proliferate. Yet, there is no other possibility. If ontology is circular, then the question that seems to come from God, and asking for a response directed towards God, is born in the very circle, and comes from nature. In fact, and here is where tautology sums itself up to the point of disappearing, the human animal "is nature that thinks of itself, [it is] nature's inner life" (Prodi 1987: 93$)^{44}$.

\section{References}

Buyssens, Eric 1943. Le langage et le discours. Bruxelles: Off. de Publicité.

Cairns-Smith, Alexander Graham 1999. Origine dei geni e struttura dei cristalli. In: Colombo, Roberto; Giorello, Giulio; Sindoni, Elio (eds.), L'intelligenza dell'universo. Casale Monferrato: Piemme, 64-73.

Cimatti, Felice 2000a. La scimmia che si parla. Linguaggio, autocoscienza e libertà nell'animale umano. Torino: Bollati Boringhieri.

- 2000b. Nel segno del cerchio: L'ontologia semiotica di Giorgio Prodi. Roma: Il manifesto Libri.

Eccles, John 1966. Facing Reality: Philosophical Adventures by a Brain Scientist. London: Harper \& Row.

Eco, Umberto 1973. Segno. Milano: Isedi.

- 1975. Trattato di semiotica generale. Milano: Bompiani.

44 "È natura che si pensa, [è] l'interiorità della natura". 


\section{Felice Cimatti}

Emmeche, Claus 1991. Det Levende Spil: Biologisk Form og Kunstigt Liv. Kobenhavn: Munksgaard (English transl.: 1994. The Garden in the Machine. Princeton: Princeton University Press).

Lo Piparo, Franco 1992. Le signe linguistique est-il à deux faces? Saussure et la topologie. Cahiers Ferdinand de Saussure 45 [1991]: 213-221.

- 1999. Il mondo, le specie animali e il linguaggio. La teoria zoocognitiva del Tractatus. In: Carenini, M.; Matteuzzi, M. (eds.), Percezione, linguaggio e coscienza: Saggi di filosofia della mente. Macerata: Quodlibet, 183202.

McDowell, John 1994. Mind and World. Harvard University Press, Cambridge (Mass.) (Italian transl.: 1999. Mente e mondo. Torino: Einaudi).

Prodi, Giorgio 1974. La scienza, il potere, la critica. Bologna: Il Mulino.

- 1977. Le basi materiali della significazione. Milano: Bompiani.

- 1982. La storia naturale della logica. Milano: Bompiani.

- 1983a. L'uso estetico del linguaggio. Bologna: Il Mulino.

- 1983b. Lingua e biologia. In: Segre, C. (ed.), Intorno alla linguistica. Milano: Feltrinelli, 172-202, 308-319.

- 1987a. Alla radice del comportamento morale. Genova: Marietti.

- 1987b. Gli artifici della ragione. Milano: Edizioni del Sole 24 ore.

- 1988a. Material basis of signification. Semiotica, 69: 191-241.

- 1988b. Teoria e metodo in biologia e medicina. Bologna: Editrice CLUEB.

\section{Циркулярный семиозис Джорджио Проди}

Семиотическая теория Проди возникает в ответ на радикальный вопрос: если знак - это кросс-референция, то чем гарантируется связь знака с объектом, к которому он отсылает? Проди отбрасывает все традиционные решения: осознанная интенция субъекта, конвенция, иконическая связь знака и объекта. Проди опровергает первый ответ, поскольку он опирается на совершенно таинственное понятие интенции. Конвенционалистский ответ также неудовлетворителен, так как распространяет на всю группу критерий, который не может быть объяснен и в случае единичного компонента. Наконец отвергается и иконический ответ, так как не объясняется понятие "сходства", лежащее в основе конщепта "иконичности". Ответ Проди локализует модель семиотических отношений в фигуре круга. Круг - это жизнь, ничто иное как бесконечная цепь отношений перевода и узнавания во все более сложных системах. В круге нет ни начала, ни конца. У него нет ни основания, ни установленного закона. Он не содержит причины, которая может стать, в свою 
очередь, следствием. Семиозис, таким образом, опирается на понятие жизни, ибо жизнь сама внутренне семиотична. Мы можем поместить мир в знаки, то есть познать его, так как сами являемся частыю этого мира, который через нас познается. Наконец, как следствие нахождения внутри круга жизни-семиозиса, встает вопрос о том, что за пределами этого круга, - проблема и эстетическая, и религиозная.

\section{Giorgio Prodi tsirkulaarne semioosis}

Prodi semiootiline teooria tekib vastusena radikaalsele küsimusele: kui märk on rist-viitav, siis millega garanteeritakse märgi seos objektiga, millele ta viitab. Prodi heidab kõrvale kõik traditsioonilised lahendused: subjekti teadlik intentsioon, konventsioon, märgi ja objekti vaheline ikooniline seos. Prodi loobub esimesest, kuna see toetub üpris ebaselgele intentsiooni mõistele. Konventsionalistlik vastus on samuti ebarahuldav, kuna kriteeriumi, mida ei ole võimalik seletada üksikkomponendi puhul, laiendadakse tervele grupile. Lõpuks heidetakse kõrvale ka ikooniline variant, kuna "sarnasuse" mõiste, mis on "ikoonilisuse" aluseks, on lahti seletamata. Prodi vastus lokaliseerib semiootiliste suhete mudeli ringi kujul. Ring - see on elu, ei midagi muud kui tõlkimise ja äratundmise suhete lõputu ahel üha keerulisemates süsteemides. Ringil ei ole ei algust ega lõppu. Tal ei ole alust ega kindlaksmääratud seaduspärasust. Ta ei sisalda ühtegi põhjust, mis ei või omakorda muutuda tagajärjeks. Semioosis tugineb seega elu mõistele, kuna elu ise on oma olemuselt semiootiline. Me võime asetada maailma märkidesse, st tunnetada teda, kuna me ise oleme selle maailma osad, mida läbi enda tunnetame. Lõpuks kerkib selle elu-semioosise ringi sees olles küsimus: mis asub sellest ringist väljaspool? See on nii esteetiline kui ka religioosne probleem. 